\title{
Sclerosis multiplex stroke jellegü tünetekkel: kihívó diagnózis egy eset kapcsán
}

\author{
Văcăraș Vitalie dr. ${ }^{* 1,2}$ - Major Zoltán Zsigmond dr. ${ }^{* 1,3}$ - Mariș Emilia dr. ${ }^{1}$ \\ Major Kinga Andrea ${ }^{4}$ - Buzoianu Anca Dana dr. ${ }^{1}$ \\ "„Iuliu Hațieganu” Orvostudományi és Gyógyszerészeti Egyetem, Kolozsvár, Románia \\ ${ }^{2}$ Kolozs Megyei Klinikai Sürgősségi Kórház, Neurológia Osztály, Kolozsvár, Románia \\ ${ }^{3}$ Kolozsvár Városi Klinikai Kórház, Neurológia Osztály, Kolozsvár, Románia \\ ${ }^{4}$ Kolozs Megyei Klinikai Sürgősségi Kórház, Intenzív Terápiás Osztály, Kolozsvár, Románia
}

\begin{abstract}
A stroke jellegú relapsus sclerosis multiplex esetén kihívást jelentő diagnózis, amelynek megállapítására gyors és hatékony döntés szükséges a megfelelő terápia kiválasztása érdekében. A szerzők az eset bemutatása kapcsán a differenciáldiagnosztikai nehézségekre összpontosítanak. A megtévesztő jelek ellenére a lépésenkénti specifikus vizsgálatokra felépített megközelítés felfedte a legvalószínúbb diagnózist és ezáltal az optimális klinikai ellátást. Orv. Hetil., 2015, $156(37), 1514-1518$.
\end{abstract}

Kulcsszavak: sclerosis multiplex, stroke jellegű szimptómák, hemiplegia, afázia

\begin{abstract}
Multiple sclerosis with stroke-like symptoms: a diagnostic challenge. Case report
Stroke-like presentation of multiple sclerosis is a challenging diagnosis requiring quick and efficient decision in order to provide the best possible therapeutical option. This case presentation focuses on the difficulties of the differential diagnostic process. Even if signs were misleading, the stepwise and structured approach with the use of adequate diagnostic tools revealed the most likely diagnosis and, thus, assured the best clinical care.
\end{abstract}

Keywords: multiple sclerosis, stroke-like symptoms, hemiparesis, aphasia

Văcăraş, V., Major, Z. Zs., Mariş, E., Major, K. A., Buzoianu, A. D. [Multiple sclerosis with stroke-like symptoms: a diagnostic challenge. Case report]. Orv. Hetil., 2015, 156(37), 1514-1518.

(Beérkezett: 2015. április 5.; elfogadva: 2015. június 13.)

*A szerzők a dolgozat elkészítésében azonos mértékben vettek részt.

\section{Rövidítések}

ADEM = akut disszeminált encephalomyelitis; CADASIL = subcorticalis infarctussal és leukoencephalopathiával járó autoszomális domináns agyi arteriopathia; CARASIL = subcorticalis infarctussal és leukoencephalopathiával járó autoszomális recesszív agyi arteriopathia; MRI = mágneses rezonanciavizsgálat; $M T H F R=$ metil-tetrahidrofolát-reduktáz; SM = sclerosis multiplex; SSEP = szomatoszenzoros kiváltott válasz; $\mathrm{VEP}=$ vizuális kiváltott válasz
A sclerosis multiplex (SM) elsősorban a fiatal felnőtteket érinti, ennek a korosztálynak az egyik legsúlyosabb kórképe. A diagnózis a módosított McDonalds-kritériumokra támaszkodik, amelyek összegzik a képalkotó adatokat, a kiváltott válaszok és az agyi-gerincvelői folyadék paramétereit és a jellemző klinikai elváltozásokat [1]. A képalkotó eljárások közül elsősorban a demyelinisatiós plakkok kimutatását célzó mágneses rezonanciavizsgálat (MRI) a legfontosabb. Ezen plakkok epizódszerüen 
vagy folyamatosan jelennek meg, és változnak a betegség előrehaladtával, vizsgálatuk diagnosztikai és követési célokra egyaránt alkalmas [2]. Ha a képalkotó eljárás kritériumai nem elégségesek, további adatokkal szolgálhatnak a kiváltott válaszok paraméterei [3] vagy az oligoclonalis sávok jelenléte az agyi-gerincvelői folyadékban, de ezek hiánya nem zárja ki a diagnózist [4].

A leggyakoribb klinikai forma a relapsusokkal/remiszsziókkal járó sclerosis multiplex, amelynek jellemzője a hirtelen megjelenő neurológiai deficit, amelyet a szimptómák lassú enyhülése követ. Az említett forma ritkán hiperakut, stroke-szerü formában is megjelenhet [5], ezekről időnként közlések jelentek meg a szakirodalomban $[6,7]$. Utóbbi klinikai kép megtévesztő lehet a diagnózis szempontjából; a közölt esetekben mind hemiparesis, mind afázia előfordult, más közlések tisztán afáziás relapsusokról számoltak be $[8,9]$. Munkánk célkitûzése egy stroke-szerú tünetekkel beutalt, valószínúsíthetően SM-betegnél tapasztalt diagnosztikai jellegzetességek bemutatása.

\section{Esetismertetés}

A 39 éves nőbeteg jobb oldali hemiplegiával (jobb végtagokon az izomerő $1 / 5$ az MRC [Medical Research Council] -skála szerint), afáziával és hangsúlyozott aluszékonysággal került felvételre. A tünetek hirtelen jelentkeztek, néhány órával felvétele előtt. Közvetlenül az epizód előtt a beteg látszólag jó egészségi állapotban volt, leszámítva egy enyhe vizeletfertőzést. A kórelőzményből említésre méltó az enyhe migrénes fejfájás és egy, a jelen kórképhez hasonló 7 évvel ezelőtti tünetegyüttes. Akkor kóros eltérést nem találtak, a CT-vizsgálat nem mutatott ki patológiás elváltozást. A tünetek gyorsan és teljesen megszúntek, a beteg a funkcionalitását visszanyerte.

A jelenlegi epizód során elvégzett CT-vizsgálat sem mutatott patológiás elemeket. Ennek ellenére a beteg három napig depléciós, hidroelektrolit-szubsztitúciós és kis molekulatömegű heparinterápiát kapott, ezalatt a kardiológiai vizsgálat sem mutatott ki kóros elváltozásokat.

Három nap után vettük át a beteget az osztályunkra, klinikailag ugyanazzal a neurológiai deficittel. A megismételt $\mathrm{CT}$-vizsgálat ischaemiát, vérzést vagy ödémára utaló jelet nem mutatott ki. A koponya-MR kicsi, disszeminált, főleg subcorticalis demyelinisatiós sérüléseket mutatott ki, amelyek nem voltak típusosak sem SM-re, sem más neuroinflammatiós kórképre, mint például a feltételezett akut disszeminált encephalomyelitisre (ADEM). A nyaki gerinc MR-vizsgálata sem mutatott ki kóros elváltozásokat. Az agyi-gerincvelői folyadék vizsgálatakor az oligoclonalis sávok negatívak voltak. A vizuális (VEP) és szomatoszenzoros kiváltott válaszok (SSEP) szintén normálisak voltak.

Mielőtt folytattuk volna a vizsgálatokat, methylprednisolonterápiát kezdtünk, 500 mg iv. öt napig, majd naponta $64 \mathrm{mg}$ öt napig, felezve a dózist minden öt nap

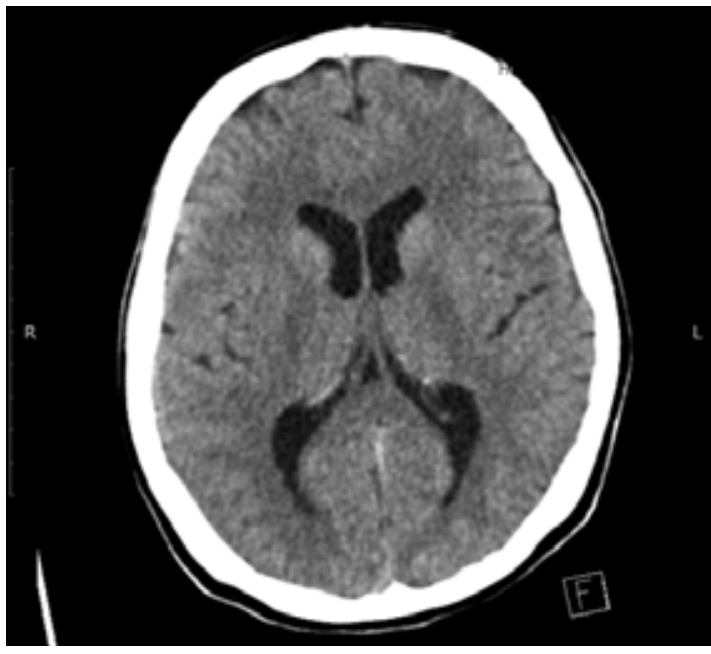

1. ábra

Sürgősségi koponya-CT. Nincs kóros elváltozás, nincsenek jelei a kezdetben felmerült stroke diagnózisának, nincs ödéma

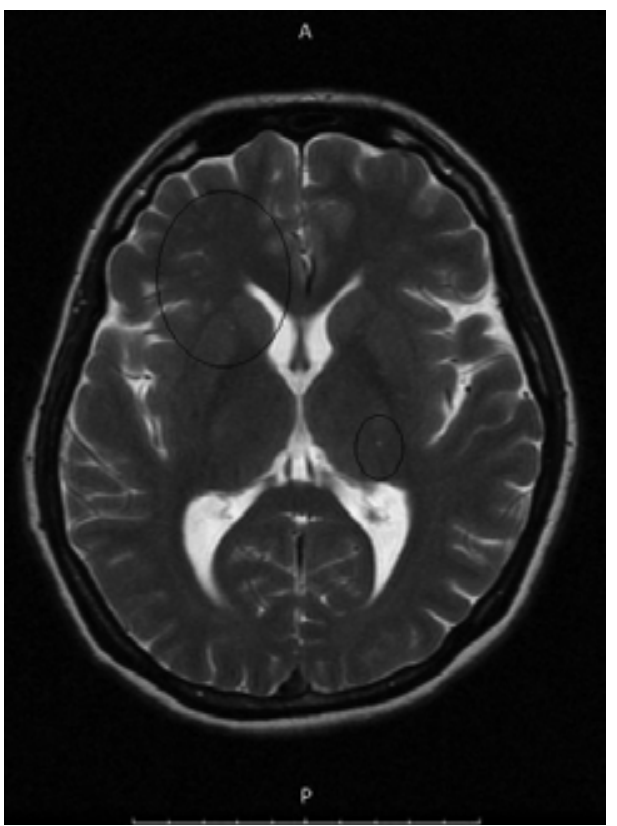

2. ábra

Nem specifikus demyelinisatiós gócok a jobb frontális régió subcorticalis részén. Egyidejű jelenlétük az ugyancsak jobb oldali hemiplegiával és afáziával nem nyújtott megfelelő topográfiai alátámasztást a diagnosztikai folyamatban

után. A terápiás döntést a diagnózis bizonytalansága (SM, avagy ADEM) sürgette. SM irányába mutatott az a tény, hogy a beteg már a második hasonló epizódjánál tartott, és a kórelőzményben nem volt fellelhető gyulladásos vagy fertőző betegség. A kezelés megkezdése után a tünetek gyorsan enyhültek, két hét után a beteg csaknem tünetmentes volt, az izomerő 4,5/5-re növekedett az MRC-skálán, ugyanakkor a beszéd kissé bradylaliás, bár érthetővé vált. A thrombophilia irányában végzett vizsgálatok kimutatták, hogy a beteg a metil-tetrahidrofolát-reduktáz (MTHFR) génjének 677 G>A mutációját hordozta, heterozigóta formában. 


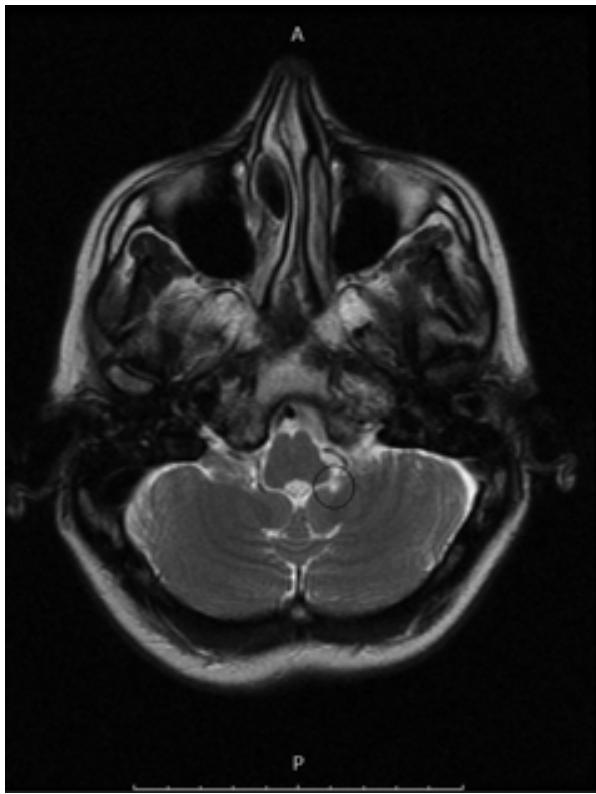

3. ábra

Pár felvételen látszanak csak demyelinisatiós gócok, az egyik a bal középső cerebellaris pedunculusban, viszont ez sem magyarázza a kórképet

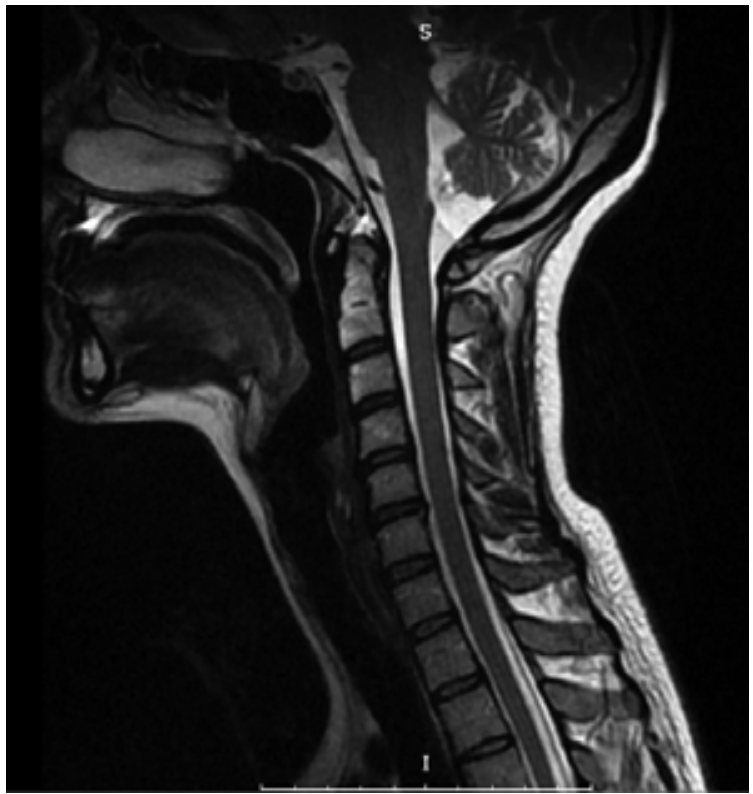

4. ábra

A nyaki gerincszakasz MR-felvételén egy jelentéktelen C5-C6 protrusio, nincs demyelinisatio

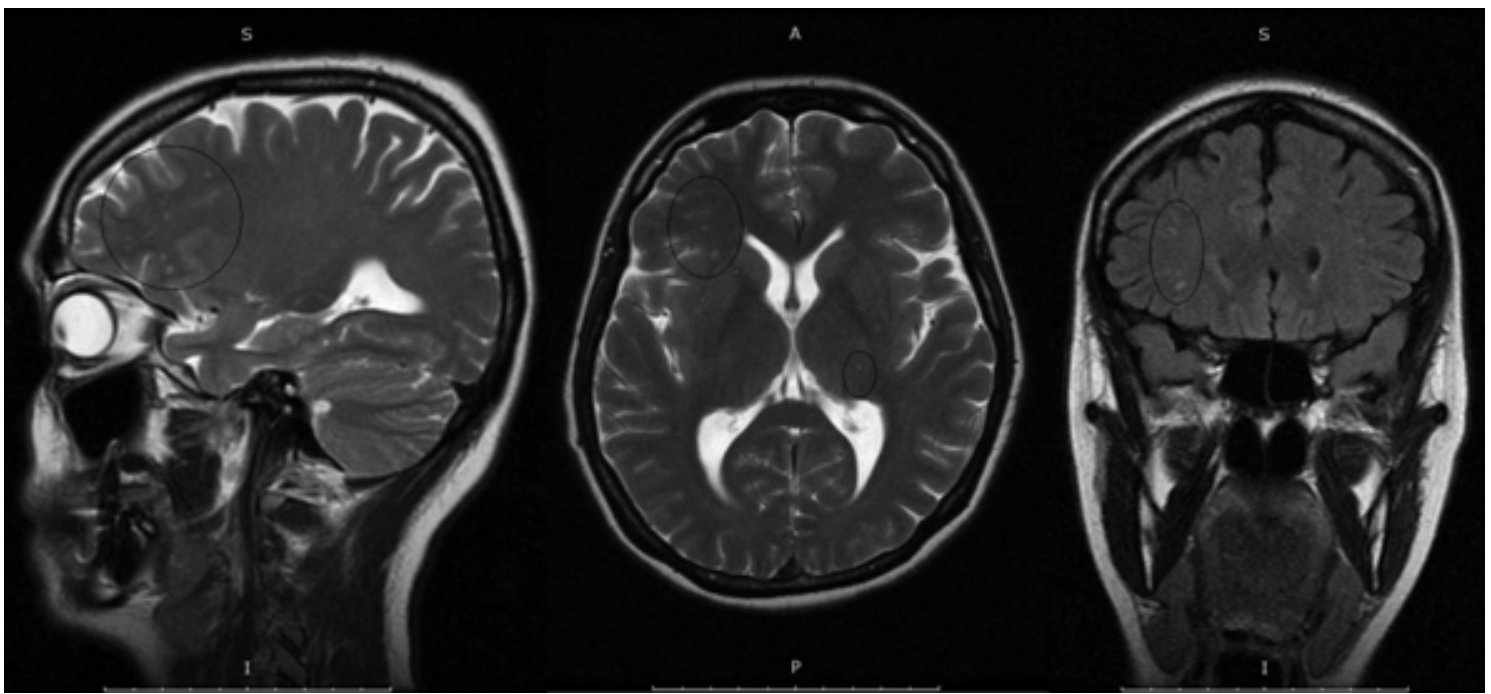

5. ábra

Kontroll-MR 6 hónappal az ismertetett epizód után és 2 hónappal a papillitis/retrobulbaris látóideg-neuritis után. Nincs számottevő különbség az említett frontális zónában

Otthonába bocsátása után a beteg egy hónapig kortikoszteroidkezelésen volt. Három hónappal később ismét jelentkezett, mindkét oldali súlyos látótér-beszüküléssel, homályos látással. A tünetek néhány nap alatt alakultak ki. A szemfenékvizsgálat papillaödémát mutatott ki, és felvetette kétoldali retrobulbaris látóideg-neuritis lehetőségét. Az újabb MR-vizsgálat nem mutatott ki számottevő elváltozást a látóidegeken, és újabb demyelinisatiós plakkok sem keletkeztek. A vizuális kiváltott válaszok csak enyhén módosultak. A kortikoszteroidterápia ismét megváltoztatta a kórlefolyást, a tünetek enyhültek, az újabb szemfenékvizsgálat az ödéma csökkenését mutatta ki, klinikailag pedig mind a látásélesség, mind a látótér-beszúkülés sokat javult. A CT- és MR-képeket, valamint a kiváltottválasz-vizsgálatokat az 1-8. ábra szemlélteti.

\section{Megbeszélés}

A bemutatott eset több diagnosztikai kérdést vetett fel. A beteg fö klinikai jellemzői a hemiplegia, az afázia és a tudat beszûkü̈lése volt; ilyen esetben részletes kivizsgálás 
Kiváltott pálaszok

Egy Surpass LT (EMS, Ausztria) készüléket alkalmaztunk a vizuális és szomatoszenzoros kiváltott válaszok regisztrálására.

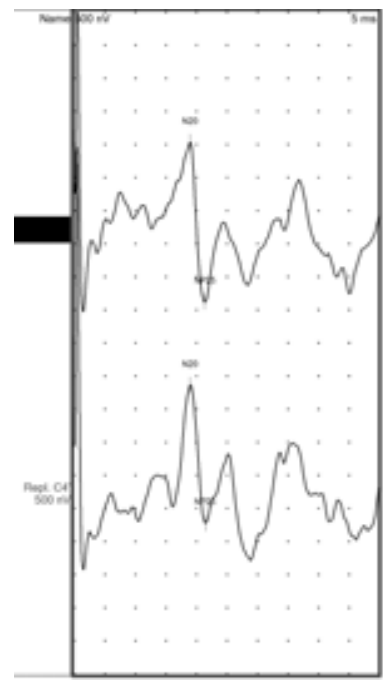

\begin{tabular}{llll}
\hline $\begin{array}{l}\text { Topog- } \\
\text { ráfia }\end{array}$ & $\begin{array}{l}\text { Kom- } \\
\text { po- }^{-} \\
\text {nens }\end{array}$ & $\begin{array}{l}\text { Laten- } \\
\text { cia } \\
(\mathrm{ms})\end{array}$ & $\begin{array}{l}\mathrm{N} 20- \\
\mathrm{NP25} \\
(\mu \mathrm{V})\end{array}$ \\
\hline $\mathrm{C} 3^{\prime}$ & $\mathrm{N} 20$ & 18,95 & 2,40 \\
Ismételt & $\mathrm{N} 20$ & 18,95 & 2,08 \\
C3' & & \\
\hline \multirow{5}{*}{ 6́bra } & $\begin{array}{l}\text { A corticalis (parietalis) } \\
\text { szomatoszenzoros ki- } \\
\text { váltott válasz a medián } \\
\text { ideg ingerlésekor nem } \\
\text { észlelhető patológiás } \\
\text { elváltozás }\end{array}$
\end{tabular}
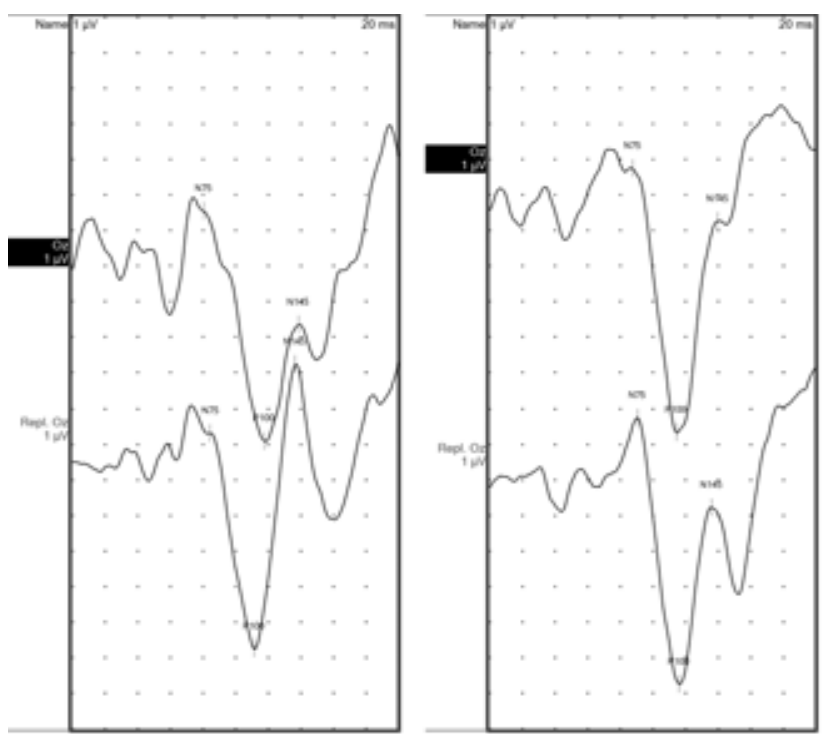

\begin{tabular}{|c|c|c|c|c|c|}
\hline Topográfia & $\begin{array}{l}\text { Lat. } \\
\text { (ms) }\end{array}$ & $\begin{array}{l}\text { Lat. } \\
\text { (ms) }\end{array}$ & $\begin{array}{l}\text { Lat. } \\
\text { (ms) }\end{array}$ & $\begin{array}{l}\text { N75- } \\
\text { P100 } \\
(\mu V)\end{array}$ & $\begin{array}{l}\text { N145- } \\
\text { Pl00 } \\
(\mu V)\end{array}$ \\
\hline $\mathrm{Bal}-\mathrm{Oz}$ & 87,63 & 114,47 & 139,73 & 7,41 & 5,92 \\
\hline $\begin{array}{l}\mathrm{Bal}-\mathrm{Oz} \\
\text { Ismételt }\end{array}$ & 90,53 & 116,05 & 135,78 & 7,50 & 4,97 \\
\hline $\mathrm{Jobb}-\mathrm{Oz}$ & 80,37 & 117,82 & 138,55 & 6,45 & 3,24 \\
\hline $\begin{array}{l}\text { Jobb - Oz } \\
\text { Ismételt }\end{array}$ & 84,73 & 111,63 & 136,37 & 6,08 & 7,96 \\
\hline
\end{tabular}

7. ábra

Kezdeti vizuális kiváltott válasz. Az N75-ös komponens enyhe latencianövekedése nem jellemző elváltozás SM-ben (pattern reversal technika)

szükséges protrombotikus állapotok, aritmiák, szívbillentyü-betegség, szív/ér malformációk kizárására, valamint képalkotó eljárások stroke kizárása céljából. A betegnél elvégzett vizsgálatok a vascularis eredetet nem támasztották alá.

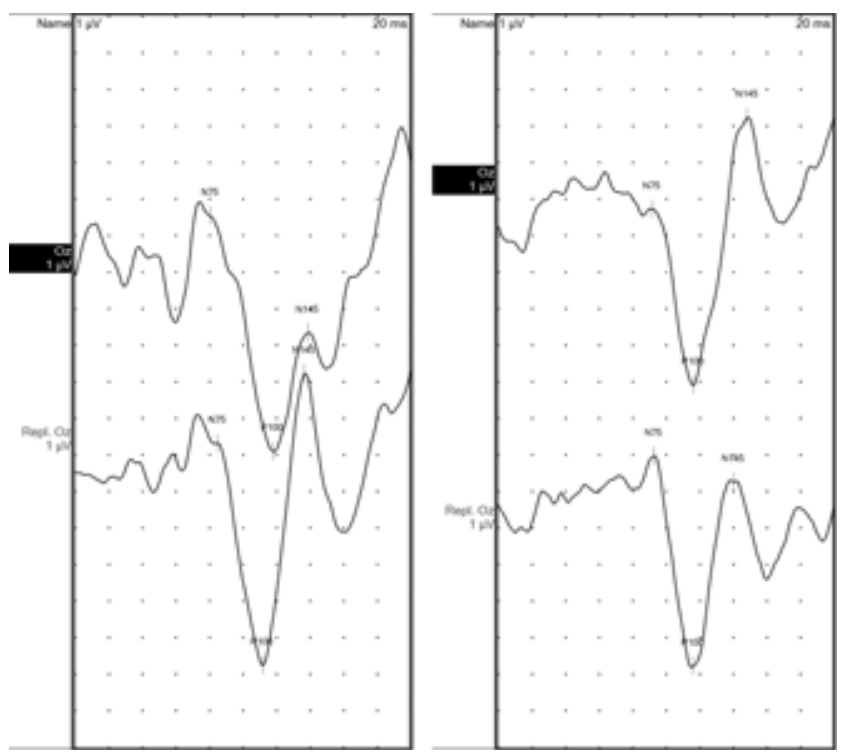

\begin{tabular}{|c|c|c|c|c|c|}
\hline Topográfia & Lat. (ms) & Lat. (ms) & Lat. (ms) & $\begin{array}{l}\text { N75-P100 } \\
(\mu V)\end{array}$ & $\begin{array}{l}\text { N145- } \\
\text { Pl00 }(\mu V)\end{array}$ \\
\hline $\mathrm{Bal}-\mathrm{Oz}$ & 91,58 & 116,05 & 148,15 & 4,82 & 7,33 \\
\hline $\begin{array}{l}\mathrm{Bal}-\mathrm{Oz} \\
\text { Ismételt }\end{array}$ & 92,63 & 115,78 & 140,00 & 5,75 & 5,05 \\
\hline $\mathrm{Jobb}-\mathrm{Oz}$ & 75,53 & 115,78 & 148,15 & 4,66 & 7,44 \\
\hline $\begin{array}{l}\text { Jobb - Oz } \\
\text { Ismételt }\end{array}$ & 77,63 & 115,78 & 145,78 & 5,03 & 8,29 \\
\hline
\end{tabular}

8. ábra $\quad$ A papillitis ideje alatt a kiváltott válasz kissé hangsúlyozottabb N75-prolongációt és az amplitúdók enyhe csökkenését mutatja

Egy másik felvetődő diagnózis volt az akut disszeminált encephalomyelitis, amely stroke jellegü kórkép formájában is jelentkezhet [10]. Ilyen esetekben a stroke jellegü tünetek kialakulása előtt gyulladásos/fertőző betegséget kell keresni. (Esetünkben csak vizeletfertőzés fordult elő a kórelőzményben.) A betegség jellegzetes MR-eltérésekkel társul és általában monofázisos lefolyású [11]. Betegünknél a kórképet kizárhattuk, a kórkép ellen a legmeggyőzőbb érv a már három dokumentált relapsus jellegú epizód volt

Felvetődött subcorticalis infarctussal és leukoencephalopathiával járó autoszomális domináns (CADASIL) és autoszomális recesszív agyi arteriopathia (CARASIL) lehetősége, de az örökletes betegségre utaló adatok hiányán kívül ezekben a kórképekben gyakran előforduló agyi ischaemiás MR-eltérések hiánya alapján ezeket a lehetőségeket nem lehetett megerősíteni. Hasonló eltérések fordulhatnak elő Binswanger-kórban is, viszont itt általában kardiológiai eltérés és hypertonia a jellemző [12], amelyek betegünk esetében hiányoztak. Mindezek ellenére teljes bizonyossággal nem zárható ki a kiserek érintettsége, tekintettel a beteg migrénes kórelőzményeire.

A fejfájás, mint kórelőzmény, újabb differenciáldiagnosztikai lehetőségként központi idegrendszeri vasculitist is felvetett, azonban a C-reaktív protein értéke nor- 
mális volt, nem voltak fellelhetőek ischaemiás elváltozások a CT- és MR-felvételeken, és az ANA-, illetve ANCAantitest-vizsgálat is negatívnak bizonyult. Ezeket az eredményeket és a normális liquorleletet (normális fehérjemennyiség, sejtszám, valamint az oligoclonalis sávok hiánya) [13] figyelembe véve az idegrendszeri vasculitis diagnózisát elvetettük [14].

Devic-betegség is felmerült egy adott ponton mint lehetőség. A klinikai jellemzők és a pedunculus cerebellaris demyelinisatiós sérülése (gyakoribb ebben a kórképben, mint SM-ben) adott némi alapot erre a felvetésre, viszont nem voltak kimutatható demyelinisatiós sérülések a gerincvelőben és a látóidegekben, és a kórlefolyás során már három relapsus fordult elő. Ezek nem jellemzőek neuromyelitis opticára, annak ellenére sem, hogy betegünket nem vizsgáltuk a 4-es aquaporin elleni antitestek jelenléte irányában [15]. Ugyanakkor e betegség jelenléte nagyon kérdéses normális SSEP és kvázi fiziológiás VEP esetén.

Végül arra a következtetésre jutottunk, hogy esetünk az SM ritka, különös megnyilvánulási formája stroke jellegű szindrómával, atípusos demyelinisatiós sérülésekkel. A kiváltott válaszok nem mutattak párhuzamot a klinikai jellemzőkkel, és a beteg liquorvizsgálata is negatívnak bizonyult. A liquorvizsgálat során az oligoclonalis sávok [16] jelenléte kevéssé specifikus a betegségre [17]. Ugyanakkor a tünetek időbeni disszeminációt mutattak: a betegnél három alkalommal fordult elő 24 óránál tovább tartó neurológiai deficittünetekkel járó epizód, amelyek után a klinikai kép gyorsan javult. Egy másik nem kevésbé fontos érv a látványos javulás volt a kortikoszteroidterápia után.

Fentiek ellenére a diagnózis továbbra is bizonytalannak mondható. Valószínű, hogy a bizonytalanság csökkenni fog, ha a betegség előrehaladtával több relapsus és több laesio jelentkezik.

\section{Következtetés}

A sclerosis multiplex diagnózisának lehetőségét fel kell vetni hasonló esetekben, amikor a kórkép szokatlan vagy a diagnosztikai kritériumok lassan, a betegség előrehaladtával teljesülnek. Ennek hiányában hosszú és értékes időt veszítünk a pozitív diagnózisig, és legfő́képpen a megfelelő kezelésig. Ilyen esetekben a betegek átfogó vizsgálata, a rendelkezésre álló diagnosztikai eljárások elvégzése és a kezelés mihamarabbi megkezdése legyen a követendő irányelv.

Anyagi támogatás: A közlemény létrejöttét az Európai Szociális Alap Humánerőforrásfejlesztő Operacionális Program 2007-2013, POSDRU/159/1.5/138776 projekt tette lehetővé.

Szerzői munkamegosztás: V. V., M. Z. Zs.: A beteg vizsgálata, a cikk megírása. M. E.: A beteg vizsgálata és do- kumentálása. M. K. A.: A beteg kezelése és dokumentálása gyógytornászként. B. A. D.: A kutatócsoport vezetőjeként a közlemény lektorálása. A kézirat végleges változatát valamennyi szerző elolvasta és jóváhagyta.

Érdekeltségek: A szerzőknek nincsenek érdekeltségeik.

\section{Köszönetnyilvánítás}

A szerzők köszönik Vlăduţiu Cristina hozzájárulását a munkához.

\section{Irodalom}

[1] Polman, C. H., Reingold, S. C., Banwell, B., et al.: Diagnostic criteria for multiple sclerosis: 2010 revisions to the McDonald criteria. Ann. Neurol., 2011, 69(2), 292-302.

[2] Traboulsee, A. L., Li, D. K.: The role of MRI in the diagnosis of multiple sclerosis. Adv. Neurol., 2006, 98, 125-146.

[3] Schlaeger, R., Schindler, C., Grize, L., et al.: Combined visual and motor evoked potentials predict multiple sclerosis disability after 20 years. Mult. Scler., 2014, 20(10), 1348-1354.

[4] Gajofatto, A., Calabrese, M., Benedetti, M. D., et al.: Clinical, MRI, and CSF markers of disability progression in multiple sclerosis. Dis. Markers, 2013, 35(6), 687-699.

[5] Przeklasa-Auth, M., Ovbiagele, B., Yim, C., et al.: Multiple sclerosis with initial stroke-like clinico-radiologic features: case report and literature review. J. Child Neurol., 2010, 25(6), 732-737.

[6] Cowan, J., Ormerod, I. E., Rudge, P.: Hemiparetic multiple sclerosis. J. Neurol. Neurosurg. Psych., 1990, 53, 675-680.

[7] Rosso, C., Remy, P., Creange, A., et al.: Diffusion-weighted MR imaging characteristics of an acute strokelike form of multiple sclerosis. Am. J. Neuroradiol., 2006, 27(5), 1006-1008.

[8] Devere, T. R., Trotter, J. L., Cross, A. H.: Acute aphasia in multiple sclerosis. Arch. Neurol., 2000, 57(8), 1207-1209

[9] Lacour, A., De Seze, J., Revenco, E., et al.: Acute aphasia in multiple sclerosis: a multicenter study of 22 patients. Neurology, 2004, 62(6), 974-977.

[10] Brinar, V. V., Poser, C. M., Basic, S., et al.: Sudden onset aphasic hemiplegia: an unusual manifestation of disseminated encephalomyelitis. Clin. Neurol. Neurosurg., 2004, 106(3), 187-196.

[11] Garg, R. K.: Acute disseminated encephalomyelitis. Postgrad. Med. J., 2003, 79(927), 11-17.

[12] Caplan, L. R.: Lacunar infarction and small vessel disease: pathology and pathophysiology. J. Stroke, 2015, 17(1), 2-6.

[13] Amara, A. W., Bashir, K., Palmer, C. A., et al.: Challenges in diagnosis of isolated central nervous system vasculitis. Brain Behav., 2011, 1(1), 57-61.

[14] Berlit, P., Kraemer, M.: Cerebral vasculitis in adults: what are the steps in order to establish the diagnosis? Red flags and pitfalls. Clin. Exp. Immunol., 2014, 175(3), 419-424.

[15] Jacob, A., McKeon, A., Nakashima, I., et al.: Current concept of neuromyelitis optica (NMO) and NMO spectrum disorders. J. Neurol. Neurosurg. Psychiatry, 2013, 84(8), 922-930.

[16] Dobson, R., Ramagopalan, S., Davis, A., et al.: Cerebrospinal fluid oligoclonal bands in multiple sclerosis and clinically isolated syndromes: a meta-analysis of prevalence, prognosis and effect of latitude. J. Neurol. Neurosurg. Psychiatry, 2013, 84(8), 909914.

[17] Petzold, A.: Intrathecal oligoclonal IgG synthesis in multiple sclerosis. J. Neuroimmunol., 2013, 262(1-2), 1-10.

(Major Zoltán Zsigmond dr., 400139, Tabacarilor street 11., Cluj-Napoca, Romania e-mail: zoltan.major@umfcluj.ro; zoltan.major@eeg-emg.ro) 